\title{
Index to Volume 1
}

\section{Articles}

Baetens, Jan, North and South in Belgian Comics 111

Gravett, Paul, De Luca and Hamlet: Thinking Outside the Box 21

Groensteen, Thierry, A Few Words about The System of Comics and More... $\quad 87$

Kuhlman, Martha, The Silence of the Page. Une trop bruyante solitude:

The Graphic Novel Adaptation of Too Loud a Solitude by Bohumil Hrabal 157

Leroy, Fabrice, 'Is There Any Boudin on the Moon?’ Depicting Cajun Ethnicity in Bec Doux et ses amis

McKinney, Mark, The Frontier and the Affrontier: French-Language Algerian

Comics and Cartoons Confront the Nation

Renonciat, Annie, Arthème Fayard's Magazines and the Promotion of Picture Stories 'à la française'

Rickman, Lance, Bande dessinée and the Cinematograph: Visual Narrative in 1895

Screech, Matthew, Autobiographical Innovations: Edmond Baudoin's Éloge de la poussière

7

Tufts, Clare, Family History and Social History: Étienne Davodeau's Reportage of Reality in Les mauvaises gens

\section{Reports}

Grove, Laurence, Web Journals

Miller, Ann, Francis Lacassin, 1931-2008

\section{Reviews}

Beaty, Bart, Unpopular Culture: Transforming the European Comic Book in the 1990 s (Catherine Labio)

Gil González, Antonio, and Anxo Tarrío Varela, eds., Olladas do Cómic Ibérico (Pedro Pérez Del Solar) 
Jessua, Alain, dir., Jeu de massacre (Hugo Frey) 213

Kunzle, David, Father of the Comic Strip: Rodolphe Töpffer (Mark McKinney) 100

McCarthy, Tom, Tintin and the Secret of Literature (J. Gavin Paul) 207

Peeters, Benoît, Lire Tintin: Les bijoux ravis (Ann Miller) 95

Töpffer, Rodolphe, Rodolphe Töpffer: The Complete Comic Strips, ed. David Kunzle

(Mark McKinney) 100 